\title{
ECONOMIC DEVELOPMENT AND ITS MEASUREMENT
}

\author{
Muhammad Erwin Soaduan Pohan \\ Institute Agama Islam Edi Hayono Madani \\ Jalan Lintas Kandis-Pekanbaru \\ muhammaderwin932@gmail.com
}

DOI: 10.46781/al-mutharahah.v18i1.266

\begin{abstract}
National development seeks to achieve fairly high economic growth, the ultimate goal of which will be to improve the quality of life and welfare for the entire community. Economic growth is interrelated with the process of increasing the production of goods and services in people's economic activities. In other words, growth is a single-dimensional development and is assessed by increasing production output and increasing income. This shows an increase in national income which is reflected by the total number of Gross Domestic Product (GDP). Indonesia, as a developing country, is in the midst of carrying out planned and gradual development, without neglecting the efforts of equity and stability in the face of the Covid-19 pandemic, which has made a number of sources of funds used to maintain public health so that for development and equitable distribution of the people's economy, the government is expected to recover immediately. People's economy slumped. Economic growth is a long-term economic problem and is a fundamental phenomenon in every country today. The process of economic growth has parameters with measurements through GNP, foreign exchange reserves, the balance of payments balance, and others. However, Islam commands humans to uphold justice in all issues related to muamalah, including economic justice. Zakat is one of the pillars in reducing the gap between the rich and the poor. QS At Taubah 60 explains that humans are entitled to receive zakat, the first 4 parties are high priority and the second 4 parties are low priority. Through the Amil Zakat Agency as an official government institution, the portrait of economic inequality can be reduced from year to year. This agency has become a reference for the international community as an innovative and massive agency or institution in helping the people.
\end{abstract}

Keywords: Development, Zakat, Economy, Baznas

Abstrak
Pembangunan nasional mengupayakan tercapainya pertumbuhan ekonomi yang cukup tinggi,
yang tujuan akhirnya akan mewujudkan peningkatan kualitas hidup dan kesejahteraan bagi
seluruh masyarakat. Pertumbuhan ekonomi saling mengait dengan proses peningkatan
produksi barang dan jasa pada aktivitas ekonomi rakyat. Dengan perkataan lain, bahwa
pertumbuhan adalah perkembangan yang berdimensi tunggal dan dinilai dengan peningkatan
hasil produksi dan bertambahnya pendapatan. Hal ini menunjukkan adanya kenaikan dalam
pendapatan nasional yang dicerminkan oleh jumlah angka Produk Domestik Bruto (PDB).
Indonesia, sebagai negara sedang berkembang ditengah bergiat melaksanakan pembangunan
terencana dan bertahap, tanpa mengabaikan usaha pemerataan dan kestabilan dihadapkan
dengan pandemi Covid 19, yang membuat sejumlah sumber dana menjadi digunakan untuk
menjaga kesehatan masyarakat sehingga untuk pembangunan dan memerataan ekonomi
rakyat terabaikan dan pemerintah diharapkan segera memulihkan ekonomi rakyat yang
terpuruk. Pertumbuhan ekonomi merupakan masalah ekonomi jangka panjang dan
merupakan fenomena mendasar pada setiap negara dewasa ini. Proses pertumbuhan ekonomi 
tersebut memiliki parameter dengan pengukuran lewat GNP, cadangan devisa, keseimbangan neraca pembayaran dan lainnya. Namun Islam memerintahkan manusia untuk menegakkan keadilan pada semua persoalan yang berhubungan muamalah, termasuk di dalamnya keadilan ekonomi.Zakat salah satu pilar dalam mengurangi kesenjangan antara si Kaya dan si Miskin. QS At Taubah 60 menjelaskan manusia yang berhak mendapatkan zakat yang 4 pihak pertama high prioritas dan 4 pihak kedua low priority. Lewat Badan Amil Zakat sebagai lembaga pemerintah yang Resmi, potret kesenjangan ekonomi dapat dikurangi dari tahun ke tahun. Badan ini telah menjadi rujukan dunia internasional sebagai Badan atau lembaga yang inovatif dan masif dalam membantu umat.

Kata kunci: Pembangunan, Zakat, Ekonomi, Baznas.

\section{A. PENDAHULUAN}

Pertumbuhan ekonomi serta pembangunan ekonomi sangatlah penting bagi suatu negara. Ekonomi dunia dalam dua puluh tahun ini menitik beratkan pada pertama, kemakmuran atau peningkatan ekonomi, kedua,bertambahnya lapangan kerja baru atau peluang kerja kepada masyarakat. Ekonomi pembangunan prinsipnya telah melewati tiga tahapan yang berbeda sebagaimana di sampaikan M.Umer Chapra ${ }^{1}$ dalam Karyanya Islam and Economic Development. Fase pertama yaitu ekonomi pembangunan klasik dikembangkan oleh para ekonom klasik yang memaparkan bahwa ekonomi jangka panjang dalam yang menjadi dasar aktivitas kapitalisme dengan semboyan laisssez faire. Fase kedua muncul setelah perang dunia kedua sehingga banyak negara dunia ketiga memperoleh kemerdekaannya. Sehingga banyak muncul negara baru yang merdeka.

Umer Chapra yang lahir di Bombay India ini menulis dalam bukunya Islam and The Economic Challenge menjelaskan bahwa di balik kemajuan ilmu ekonomi yang begitu pesat. $^{2}$

Teori pertumbuhan Harrod-Domar adalah salah satu teori pertumbuhan ekonomi modern yang menitik beratkan arti pentingnya pemberian investasi bagi pertumbuhan ekonomi. Bila investasi tinggi berakibat baik pula perekonomian suatu negara, investasi memberi pengaruh yang kuat terhadap besarnya permintaan agregat yang berimplikasi kepada penawaran agregat $\mathrm{I}+\mathrm{S}$ melalui dampaknya kepada besarnya produksi. Dalam perspektif kedepan, besarnya investasi akan menambah stok kapital. ${ }^{3}$

Menurut Khursyid pembangunan meliputi aspek moral dan $\operatorname{sosial}^{4}$, material dan spritual. Khursyid memaparkan bahwa pertumbuhan ekonomi berhubungan erat dengan keadilan distribusi pendapatan dan kekayaan bagi setiap muslim pada seluruh generasi, mendirikan shalat menunaikan zakat.

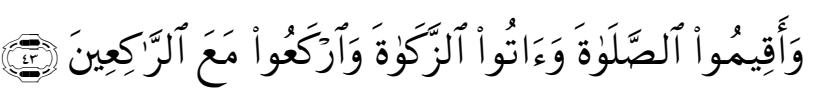

Dan dirikanlah shalat, tunaikanlah zakat dan ruku'lah beserta orang-orang yang ruku' (Q S Albaqarah 43) ${ }^{5}$.

Konsep pertumbuhan ekonomi menurut Islam dengan kapitalisme dan sosialisme bahwa sistem ekonomi Islami berasaskan filsafat yang berhubungan 3 point yaitu: altauhid, al-rububiyah dan al-istikhlaf. Al-Fasi memaparkan perbedaan yang menyebabkan

\footnotetext{
${ }^{1}$ M. Umar Chapra, Islam and Economic Development, (Jakarta: Gema Insani, 2000), hal.

${ }^{2}$ M. Umar Chapra, Islam and The Economic Challenge, (Yogyakarta: Dana Bhakti Wakaf, 1998), hal.

3 Ahmad Ma'aruf dan Latri Wihastuti, Pertumbuhan Ekonomi Indonesia: Determinan dan Prospeknya, Jurnal Ekonomi dan Studi Pembangunan, Volume 9, Nomor 1, April 2008, hlm. 44-45.

${ }^{4}$ Khursyid Ahmad, 85.Al-Tanmiyah al-iqtisodiyah fi ithorin islamiyin, terjemah Rafiq Al-misri, Majalah Abhas al-iqtisod al-islami, nomor 2, bagian 2, hal 5-46.

5 Al Quranul Karim QS Albaqarah 43
} 
sistem kapitalisme yang membolehkan riba dan sistem sosialisme yang terlepas dari nilai agama. $^{6}$

Yusuf Qardhawi berpendapat bahwa pemberlakuan al-urf untuk mengetahui pertumbuhan ekonomi kurang tepat kepada masyarakat muslim. ${ }^{7}$ Menurut Abdul Mannan perbedaan disebabkan adanya persoalan yang tidak populer yang tidak bisa menjadi dasar bagi pembangunan ekonomi pada masyarakat non muslim. Pertumbuhan ekonomi masyarakat muslim bersumber pada Al-Quran dan as-sunnah. ${ }^{8}$

\section{B. METODOLOGI}

Metodologi yang dipakai adalah jenis metodologi Historis dan Metodologi kasus. Jenis metodologi ini mengkaji masa lalu secara sistematis dan obyektif sedangkan kasus sebagai praktek yang bisa di paparkan secara komperhensif dan intensif tentang kondisi sekarang serta interaksi lingkungan pada suatu objek .

\section{PEMBAHASAN}

Landasan konsep pembangunan ekonomi kita kutip ayat Al-Qur'an sbb:

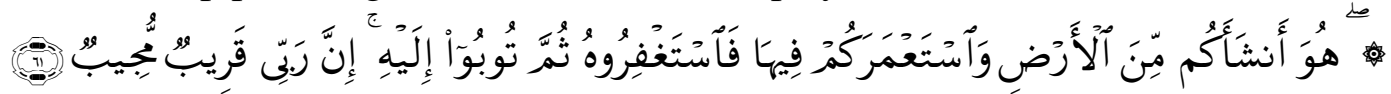

Dia telah menciptakan kamu dari bumi (tanah) dan menjadikan kamu pemakmurnya, karena itu mohonlah ampunan-Nya, lalu bertobatlah kepada-Nya, Sesungguhnya Tuhanku Amat dekat (rahmat-Nya) lagi memperkenankan (doa hamba-Nya)."

Dalam ayat ini terkandung dua makna dengan pembangunan ekonomi yaitu: Pertama Kewajiban umat manusia ( Al-wujub ) untuk mengelola bumi sebagai lahan pertanian dan pembangunan. Kedua, Perintah Allah Azza Wa Jalla kepada umat manusia untuk membangun Alam Semesta dan Perintah Allah tersebut bersifat wajib serta mutlak. Penulis berpendapat kata al-'imarah (memakmurkan) identik dengan kata at-tanmiyah al-iqtisadiyah (pembangunan ekonomi).

M. Umer Chapra, dalam buku Islam and Economic Development, memaparkan bahwa salah satu point penting untuk menjalankan dan mempercepat pertumbuhan yang berkeadilan adalah dengan menjadikan masyarakat dan individu untuk mampu secara optimal mengunakan daya kreasi dan artistik dengan profesional, produktif dan efisien. ${ }^{\mathbf{9}}$

Semangat entrepreneurship dan kemandirian harus ditumbuh kembangkan dan dibangun dalam jiwa masyarakat. Dr. Muhammad Yunus menitikberatkan pentingnya pembentukan semangat kewirausahaan dalam peningkatan ekonomi di negara-negara muslim dengan kategori kurang mampu. Beliau menjelaskan bahwa "Upah buruh bukan jalan untuk mengurangi kemiskinan dan wirausahalah yang mempunyai peluang lebih besar dalam meningkatkan basis-basis asset individual dari pada yang dimiliki oleh upah kerja ${ }^{\mathbf{1 0}}$.

Semangat kewisahausahawaan akan mendorong pengembangan usaha kecil secara signifikan. Usaha kecil pada sektor produksi akan menyerap tenaga kerja yang banyak dan jauh lebih besar. Oleh karena itu Hasan Al-Banna memberikan dan mengembangkan industri

${ }^{6}$ Al-Syaikh 'Allal Al-Fasi, 1971. Al-Islam wa mutatollabat al-tanmiyah fi mujtama' al-yaum (Darran: Multaqa al-fikr al-Islami), hal. 29

${ }^{7}$ Ibrahim Yusuf. 1981. Istiratijiyatu wa Tiknik al-Tanmiah al-Iqtisodiyah fi al-Islam (Kairo: Al-Ittihad alDauli li al-Bunuk al-Islamiyah), hal. 221.

${ }^{8}$ Muhammad Abd al-Mannan. tt. Al-Iqtisâd al-Islâmi baina al-nazariyat wa al-tathbiq (Al-Maktab al-ârabi al-hadis), hal. 27.

9 M.Umer Chapra, Islam and Economic Development, USA, The Internasional Institute of Islamic Though (IIIT), 1992 hlm 136

${ }^{10}$ Muhammad Yunus, The Poor as the Engine of Development, dalam Economic Impact, 2 (1988). hlm. 31 
rumah tangga yang utama dalam pembahasan tentang reformasi ekonominya sesuai dengan ajaran Islam. Beliau menekankan karena membantu menyediakan lapangan kerja produktif bagi semua anggota masyarakat miskin, dengan demikian akan mengurangi pengangguran dan kemiskinan. ${ }^{11}$ Kondisi kenyataannya adalah potret kemiskinan semakin besar, apalagi dengan adanya bencana Covid 19 yang berdampak kepada lesunya ekonomi, kurangnya daya beli yang dipicu oleh berkurangnya konsumsi, produksi yang menurun yang berdampak kepada PDB yang kecil.

Pembangunan ekonomi memiliki tolak ukur diantaranya adalah Pendapatan Nasional, Produk Nasional Bruto (GNP), peluang kerja, kestabilan dalam ekonomi, cadangan devisa yang terjaga dan pemerataan pendapatan.

\section{Pendapatan Nasional}

Pendapatan Nasional adalah cara perhitungan yang dipergunakan untuk mengukur aktivitas ekonomi yang terjadi atau yang berlangsung di dalam perekonomian. Dengan adanya perhitungan pendapatan nasional akan membantu untuk mengetahui tingkat kemakmuran suatu negara dan membuat pengaturan dan pelaksanaan kegiatan pembangunan yang berkelanjutan. Pendapatan nasional merupakan seluruh pendapatan yang diterima oleh seluruh masyarakat dalam kurun satu tahun.

Meskipun penting memformulasikan konsep Islam tentang pembangunan ekonomi, namun namun penulis mengambil indikator dari sisi GDP. Indikator pembangunan yang sering dirujuk dalam mengevaluasi pertumbuhan pendapat nasional yaitu GNP atau GDP.

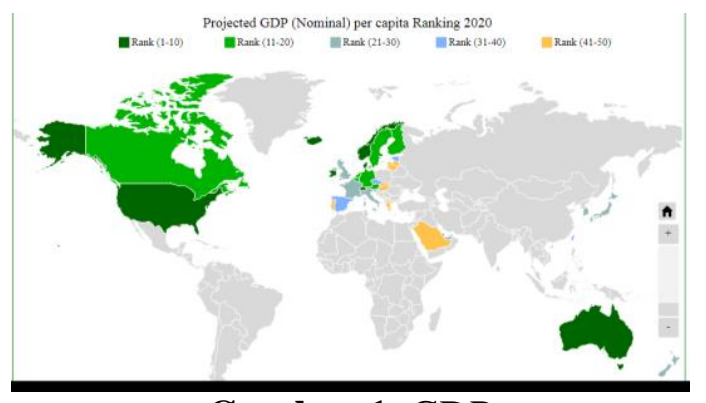

Gambar 1. GDP

Tabel 1. Sumber: Bank Dunia 2020

\section{GDP (Nominal)}

per capita

Ranking

Country/

Economy

GDP per capita (Nominal) (\$)

Growth GDP (Nominal) (\$)

(\%)

\begin{tabular}{lrcccccc} 
& $\mathbf{2 0 1 9}$ & Rank & $\mathbf{2 0 2 0}$ & Rank & $\mathbf{2 0 2 0}$ & $\mathbf{2 0 2 0}$ & Rank \\
\hline Luxembourg & 115,83 & 1 & 109,60 & 1 & -5.80 & 68.61 & 70 \\
\hline Switzerland & 9 & & 2 & & & & \\
\hline Ireland & 82,484 & 2 & 81,867 & 2 & -5.30 & 707.9 & 18 \\
\hline Norway & 80,504 & 3 & 79,669 & 3 & -3.00 & 399.1 & 29 \\
\hline United States & 75,294 & 5 & 67,989 & 4 & -2.83 & 366.4 & 33 \\
\hline Singapore & 65,254 & 7 & 63,051 & 5 & -4.27 & 20,807 & 1 \\
\hline Denmark & 65,234 & 8 & 58,484 & 6 & -6.00 & 337.5 & 39 \\
\hline Iceland & 59,770 & 10 & 58,439 & 7 & -4.50 & 339.6 & 38 \\
\hline Qatar & 67,857 & 6 & 57,189 & 8 & -7.15 & 20.81 & 111 \\
\hline
\end{tabular}

\footnotetext{
${ }^{11}$ Hasan Al-Banna, Majmu'at at-Rasail, Alexandaria, Darud Dakwah, 1989, hlm 267
} 


\begin{tabular}{llllllll}
\hline Australia & 54,348 & 11 & 51,885 & 10 & -4.16 & 1,335 & 13 \\
\hline World & 11,557 & & 10,954 & & -4.36 & 83,845 & \\
\hline
\end{tabular}

Dari tabel diatas kita dapat menyimpulkan bahwa besarnya pembangunan dan pertumbuhan ekonomi muncul pada negara yang tingkat kesenjangan ekonominya kecil, pendapatan perkapitanya besar dan pendidikan untuk masyarakatnya maju.

\section{Produk Nasional Bruto (GNP)}

GNP adalah Total nilai produk barang dan jasa yang dihasilkan masyarakat dalam negara pada periode tertentu, biasanya satu tahun, termasuk di dalamnya barang dan jasa yang dihasilkan oleh masyarakat negara yang terdapat di luar negeri.

\section{Sumber kenaikan pertumbuhan ekonomi umumnya muncul melalui:}

a. Kenaikan penawaran tenaga kerja

Kebutuhan tenaga kerja yang banyak akan menghasilkan out put banyak bila disertai modal yang banyak., namun apabila stok modal tetap kemudian jumlah tenaga kerja naik, tenaga kerja baru memiliki cenderung akan unproduktif.

b. Kenaikan modal fisik atau sumber daya insani

Modal fisik dapat menaikkan produktivitas sumber daya insani maupun penyediaan langsung jasa yang paripurna.

c. Kenaikan produktivitas

Meningkatnya produktivitas masukan apabila setiap unit memberikan kontribusi dengan memproduksi lebih banyak hasil. Apabila pengusaha Indonesia memiliki usaha garment di Malaysia, hasil berupa uang dari garment menjadi nilai tambah terhadap GNP. GNP adalah Pendapatan WNI Dalam Negeri + Pendapatan WNI Luar Negeri- Pendapatan Asing Dalam Negeri

d. Kesempatan Kerja

Pertambahan penduduk berarti bertambahnya sumber daya insani dan menjadi pertambahan hasil yang berkurang mengakibatkan kenaikan output semakin kecil, penurunan produk rata-rata serta penurunan taraf hidup. Apabila tidak didukung oleh kecanggihan teknologi, kualitas serta ketrampilan manusianya maka akan mengurangi GNP kita.

\section{Perekonomian yang stabil}

Perekonomian yang stabil artinya tingkat pendapatan yang dimiliki Negara tersebut relatif stabil ditambah dengan perkembangan ekonomi yang bertumbuh positif.

\section{Distribusi Pendapatan yang merata}

Pertumbuhan ekonomi terjadi bila ada kenaikan output perkapita. Pertumbuhan ekonomi digambarkan dengan kenaikan kualitas hidup yang dinilai dengan peningkatan pendapatan riil per orang. Dengan perkataan lain distribusi pendapatan yang merata akan memudahkan suatu Negara untuk merencanakan pembangunannya.

\section{Neraca Pembayaran Luar Negeri}

Hal yang paling mendasar pada neraca pembayaran Luar Negeri adalah Neraca Transaksi Berjalan (Current Account), yaitu merupakan gabungan antara Neraca Perdagangan (eksporimpor) dan Neraca Jasa yang mencakup jasa faktor produksi dan jasa non faktor produksi. Tujuan diciptakan syari'ah yakni kemaslahatan manusia di dunia dan di akhirat sebagai aspek inti dapat diwujudkan.

Kita kembali ke konsep Islam, ada lima unsur pokok maqashid syariah itu adalah agama, jiwa, keturunan, akal dan harta. Dimana memiliki tiga tingkatan yaitu:

1) Maqashid al-daruriyaat.

2) Maqashid al-hajiyaat

3) Maqashid al-Tahsiniyat. 
Tidak terwujudnya aspek daruriyaat dapat merusak kehidupan manusia dunia dan akhirat walaupun kehidupan dunia megah namun yang diutamakan kehidupan akhiran kelak. Ketidaksempurnaan pada aspek hajiyaat, tidak sampai menciderai kelima unsur pokok diatas, akan tetapi hanya membawa kepada kesulitan bagi manusia sebagai mukallaf dalam mewujudkannya. Contohnya dalam memelihara unsur agama, aspek daruriyaatnya seperti mendirikan shalat. Shalat merupakan aspek daruriyaat, menghadap kearah kiblat merupakan aspek hajiyaat, dan pakaian yang baru merupakan aspek tahsiniyat.

Apabila kita analisa lebih jauh, dalam usaha mencapai menjaga kelima point diatas secara sempurna, maka ketiga tingkat maqashid di atas tidak dapat dipisahkan. Tampaknya bahwa tingkat hajiyaat adalah penyempurnaan tingkat daruriyaat. Tingkat tahsiniyat merupakan penyempurnaan bagi tingkat hajiyaat. Sedangkan daruriyaat menjadi pokok hajiyaat dan tahsiniyat.

Kebijakan pembangunan ekonomi (economic development) yang disertai dengan keadilan dan stabilitas berdasarkan pemikiran Umar Chapra, yaitu:

1. Memberikan kenyamanan kepada faktor manusia

2. Mereduksi konsentrasi kekayaan

3. Melakukan restrukturisasi ekonomi

4. Melakukan restrukturisasi keuangan, dan

5. Rencana kebijakan strategis ${ }^{12}$

Pembangunan ekonomi menurut islam penting, namun tetap menempatkannya pada persoalan pembangunan yang lebih besar, yaitu pembangunan umat manusia. Islam memberikan guidience (panduan) yaitu membimbing manusia pada jalan yang benar untuk mendapatkan falah. Pembangunan ekonomi harus bersumber kepada Al Quran dan Hadist untuk kemakmuran dunia dan akhirat.

Menurut pemaparan Abdullah Abdul Husein At-Tariqy ${ }^{13}$ bahwa "Ahli ekonomi islam dan para fuqaha banyak menitik beratkan terhadap persoalan pertumbuhan ekonomi. Menurut beliau, pertumbuhan ekonomi bukan hanya aktivitas produksi material tapi merupakan aktivitas menyeluruh dalam bidang produksi yang terkait erat dengan keadilan distribusi. Pertumbuhan ekonomi tidak hanya diukur dari aspek ekonomi, melainkan aktivitas manusia material dan spiritual manusia sekaligus.

Professor M.A. Mannan menjelaskan bahwa konsep pembangunan Islam berbeda dengan konsep pembangunan modren yang konvensional. Keunggulan tersebut terletak pada motivasi pembangunan ekonomi dalam Islam, tidak hanya dari masalah ekonomi manusia tetapi juga dari tujuan ilahi yang tertera dalam Al-quran dan Hadits. ${ }^{14}$

\section{Peranan Zakat dalam Membiayai Pembangunan}

Zakat merupakan instrumen keuangan penting umat islam yang memiliki peran pokok dalam merealisasikan kepedulian sosial dan redistribusi pendapatan antara umat Islam. Zakat dapat mendorong pertumbuhan ekonomi 8 (delapan) asnaf sehingga bisa mandiri. Sehubungan dengan peran zakat untuk pemberantasan kemiskinan dan pengurangan ketimpangan pendapatan, banyak studi empiris yang membahas tentang masalah penggunaan pendekatan kuantitatif di Indonesia. Irfan Syauqi Beik menggunakan alat analisis untuk mengukur kemiskinan dan ketimpangan pendapatan. Hal ini termasuk kurva Lorenz yang paling umum digunakan. Dengan mengambil kasus kota Jakarta, dia menemukan program

\footnotetext{
${ }^{12}$ M.Umer Cahpra, Islam and Economic Development, op.cit, hlm 84

${ }^{13}$ Abdullah Abdul Husein At-Tariqy, Ekonomi Islam: Prinsip, Dasar dan Tujuan, (Yogyakarta: Magistra Insania Press, 2004), hal.

14 M.Abdul Mannan, Islamic Economiys, Theory and Practice, terj. M.Nastangin, Teori dan Praktek Ekonomi Islam, Yogyakarta, Dana Bakti Waqaf, 1997, hlm. 393-394
} 
distribusi zakat yang mampu mengurangi angka kemiskinan dan ketimpangan pendapatan sebesar 16,79 persen dan 0,57 poin persentase masing-masing (Beik, 2013) ${ }^{15}$.

Zakat adalah instrumen ibadah yang memiliki sisi sosial ekonomi yang sangat kuat. Dalam QS. Albaqarah 276 dan QS. Thaha 39, salah satu fungsi zakat adalah sebagai antitesa dari sistem perekonomian ribawi. Artinya, upaya memerangi sistem riba tidak akan berjalan dengan baik apabila institusi zakat tidak dapat diopmalkan (Ayuniyyah dkk, 2017) ${ }^{16}$. Secara ekonomi, potensi zakat di negara-negara islam menurut studi Monzzer Kahf (1989) adalah berkisar antara 184,34 persen dari total PDB masing-masing. Jika dikalkulasikan saat ini, dengan total PDB yang ada, maka potensi zakat dunia Islam mencapai angka dari 600 miliar Dollar setiap tahunnya, atau sekitar Rp 8.400 triliun dengan nilai tukar USD $1=$ Rp 14 ribu

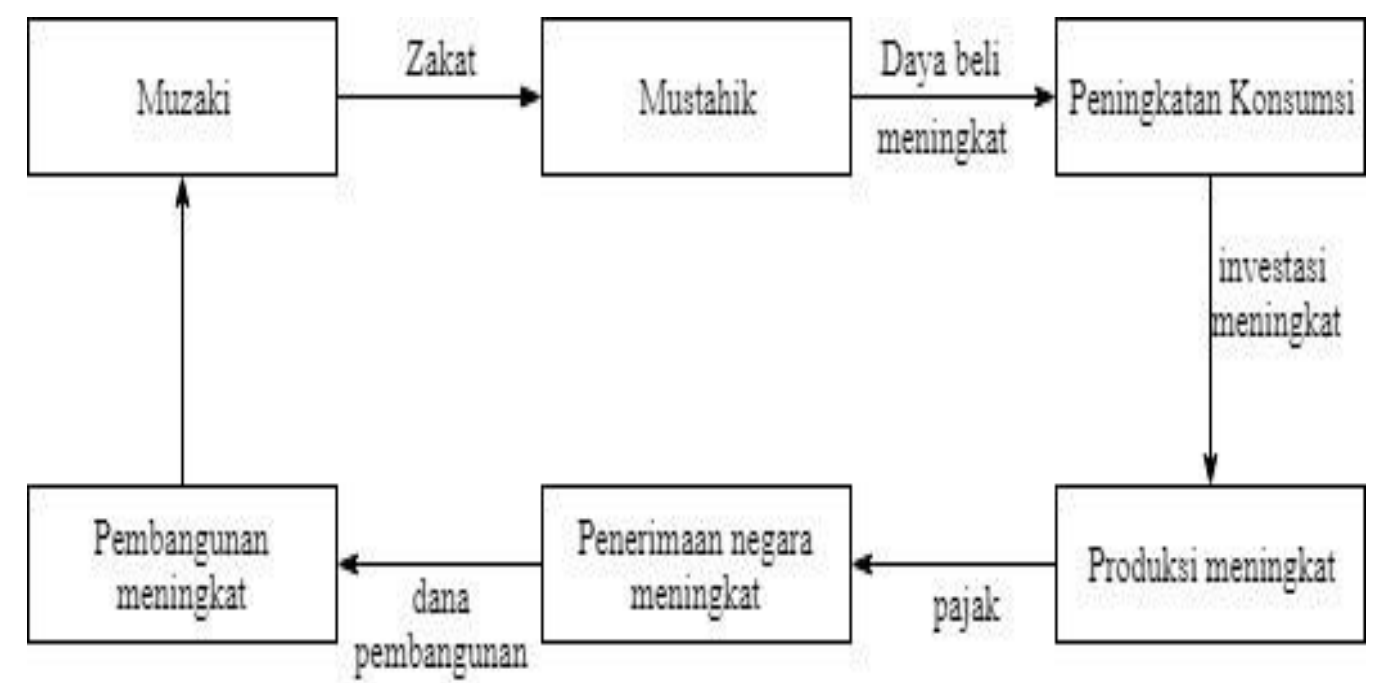

Gambar 2. Efek Zakat dalam Perekonomian Negara

Gambar 2 adalah penjelasan bahwa zakat memiliki dampak multiplier secara sosial dan ekonomi masyarakat. Bantuan zakat konsumtif yang didistibusikan kepada mustahik untuk memenuhi kebutuhannya. Peningkatan daya beli atas suatu barang ini akan memicu pada peningkatan produksi barang suatu perusahaan, sehingga akan menyerap sumber daya insani yang banyak. Peningkatan tersebut tentunya berdampak positif terhadap roda ekonomi.

Sumber dana penggeraknya, yang pertama, adalah zakat yang wajib. Zakat yang diwajibkan Allah atas harta orang-orang yang punya untuk jangka waktu nishab yang ditentukan syariah bertujuan membersihkan jiwa- diri dan menumbuhkan harta Muzaki: "Yang diambil dari kaum kaya mereka dan diserahkan kepada kaum miskin mereka", dan disalurkan pada ke delapan asnaf (alokasi penyaluran) yang telah ditentukan oleh al-Qur'an At Taubah 60 dengan analisa sebagai berikut:

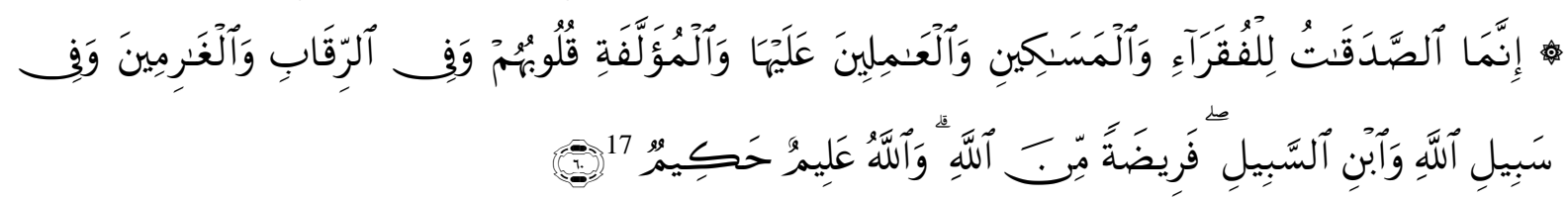

15 I.S. Beik, Ekonomic Role of zakat in Reducing Poverty Ang Income Inequality: A Case Study in the Province of DKI Jakarta, Indonesia, (Deutschland: LAP Lambert Akademic Publishing, 2013), hal.

16 Ayuniyyah Qurroh dkk, The Comparison between Comsumption and Production-based Zakat Distribution Programs for Poverty Alleviation and Income Inequality Reduction, International Journal of Zakat Vol 2 (2) 2017 hal. 11 - 28.

17 Al Quranul Karim At Taubah 60 
Analisa dari ayat tersebut terdapat:

Orang/pihak pertama yang menjadi High Prioritas:

1. Fakir (pendapatan kurang dari 50\% dari kebutuhan pokok yang wajar)

2. Miskin (pendapatan $60-70 \%$ dari kebutuhan pokok yang wajar)

3. Amil (Pengurus Zakat yang ditunjuk pemerintah)

4. Mualaf (orang yang dilembutkan hatinya)

Orang/pihak kedua yang menjadi Low Prioritas

5. Budak (orang yang terbelenggu, kecanduan dsb)

6. Orang yang berhutang (untuk kebutuhan pokok)

7. Orang dalam perjalanan (tujuan jelas dan baik)

8. Fisabillillah (orang yang berjuang di jalan Allah SWT) ${ }^{18}$

Penulis menyampaikan perlunya peningkatan zakat sebagai sumber dana melalui cara infaq. Zakat mempunyai peranan untuk memberikan kepemilikan bagi fakir miskin berupa sarana produksi seperti memberikan mereka rumah untuk tempat tinggal atau alat yang dipakai untuk bekerja atau modal usaha. Dan selama kita boleh memperoleh zakat berupa barang modal maka boleh pula bagi kita untuk mendistribusikan zakat tersebut dalam bentuk barang modal dan ini akan menjadi alat produksi bagi fakir miskin.

Peranan zakat tidak hanya terbatas untuk masyarakat lokal karena menurut Al-Jundi zakat itu boleh didistribusikan di berbagai tempat di negara negara Islam apabila kebutuhan masyarakat miskin lokal sudah tercukup. ${ }^{19}$

Pertama, tahap formulasi. Sebagai contoh penulis memaparkan Strategi. Badan Amil Zakat Provinsi Riau dalam menghadapi perkembangan zaman kekinian melakukan formulasi strategi dengan mengubah mindside paradigma dari sebuah lembaga yang tradisional dan konvensional menjadi lembaga yang modern berbasis Informasi Teknologi (IT).

Masyarakat dan pengusaha menurut Ramdani ingin kemudahan dalam mengakses lembaga zakat karena mereka memiliki aktivitas yang cukup padat dan mobilitas yang tinggi. Baznas Provinsi Riau akan memberi kemudahan dengan teknologi, berzakat memakai Handphone. Aplikasi zakat di handphone mempermudah akses masyarakat untuk melihat program Badan Amil Zakat. Upaya formulasi Baznas ini merupakan bagian dari manajemen atau kemampuan mengarahkan dan mencapai hasil yang diinginkan dengan pemberdayaan insani dan sumber daya lain.

Adapun Tentang pelaksanaannya mengacu pada UU no.23 tahun 2011 tentang Pengelolaan Zakat dan dikuatkan melalui PP No tahun 2014 tentang pelaksanaan UU no 23 tahun 2011 tentang Pengelolaan Zakat. Melakukan komunikasi formal dengan SKPD Provinsi Riau, Instansi Vertikal seperti kantor wilayah kementrian Agama, kantor keuangan, kantor pajak, Perguruan Tinggi, Badan Usaha Milik Daerah dan Masjid Annur Pekanbaru.

Proses tersebut dilakukan amil zakat Badan Amil Zakat Nasional Provinsi Riau. Komunikasi formal berupa, pemberian surat dengan mengundang kepada SKPD Provinsi Riau kantor pajak, kantor keuangan, Perguruan Tinggi, BUMD. Mengajak mereka audiensi guna tercapainya kegiatan Baznas mengajak mereka menjadi muzaki bagi yang telah mencapai nisab, sehingga dapat mengentaskan kemiskinan di Riau pada khususnya dan di Indonesia pada umumnya.

Komunikasi non formal yang terjadi secara spontan, misalnya sumbang saran yang

18 Team Baznas Provinsi Riau, Buku saku Zakat 2017

${ }^{19}$ Muhammad Al-Syahat Al-Jundi. 1985. Qowa'id al-Tanmiyah al-Iqtisodiyah fi alQanun al-dauli wa alfiqh al-islami (Kairo: Dar al-nahdah al-Arabiyah), hal. 59-83. 
berkaitan dengan tugas, kewajiban. Baznas Prov. Riau juga melakukan komunikasi non formal namun lebih menekankan pada aspek human relationsnya. Atau dengan kata lain digunakan dalam permasalahan diluar pekerjaan secara langsung, seperti komunikasi jaringan pribadi, Keluarga, maupun kerabat dekat dari setiap ketua-ketua Badan Amil Zakat Nasional Provinsi Riau.

Kedua, Tahap Implementasi. Implementasi dari kegiatan pengumpulan zakat dilakukan pada proses pengembangan perluasan daerah pengumpulan zakat maal. Terkhusus pimpinan antar lembaga sebagai wajahnya adalah pimpinan Badan Amil Zakat Nasional Provinsi Riau.

Pertama, sosialisasi dan edukasi zakat kepada seluruh masyarakat secara berjenjang dan terstruktur. Sehingga kegiatan zakat dirasakan getarannya oleh seluruh masyarakt. Sosialisasi tentang hikmah tujuan dan manfaat zakat bagi pembangunan karakter dan kesejahteraan bangsa. Kaitan zakat dengan berbagai dimensi kehidupan, termasuk kegiatan ekonomi dan keharusan berzakat melalui amil zakat. Program sosialisasi dan edukasi zakat didukung oleh pemerintah melalui Undang-undang No.23 tahun $2011^{20}$ tentang Pengelolaan Zakat Peraturan Pemerintah (PP) No.14/2014 tentang Pengelolaan Zakat ${ }^{21}$ dan Inpres No 3/2014 tentang Optimalisasi pengumpulan zakat melalui BAZNAS pusat maupun daerah ${ }^{22}$.

Kedua, Penguatan BAZNAS sebagai amil, menyangkut Sumber Daya Insani yang memiliki integritas pribadi yang kuat, amanah, dan profesional. Selain itu juga harus memiliki pengetahuan tentang zakat dan manajemennya yang memadai dan memiliki waktu yang cukup. Sistem Informasi Teknologi lembaga harus juga canggih, memiliki database muzakki dan mustahik yang akurat, serta koordinasi yang baik dengan Baznas Pusat.

Ketiga, program pendistribusian dan pendayagunaan zakat yang tepat sasaran, baik konsumtif maupun produktif skala prioritas yang sejalan dengan urgensi untuk mustahik di daerah. Perencanaan, pelaksanaan dan evaluasi program yang dilakukan secara tepat.

Keempat, penguatan regulasi dan aturan tentang pengelolaan zakat. Menguatkan dan mengejawantahkan ketiga aturan tersebut diatas ditambah dengan peraturan-peraturan Badan Amil Zakat Nasional, agar semuanya berjalan dengan baik.

Kelima, sinergi dan koordinasi dengan semua pihak, termasuk dengan Lembaga Amil Zakat (LAZ) pusat maupun daerah, dengan ormas Islam, dengan lembaga pendidikan dan dakwah, Dewan Masjid Indonesia, pondok pesantren serta semua simpul-simpul masyarakat. ${ }^{23}$

Tahap implementasi ini merupakan bagian yang krusial, karena pelaksanaan dari pihak yang berwenang ketika mengambil keputusan untuk menetapkan tujuan tahunan, membuat kebijakan, memotivasi pegawai, dan mengalokasikan sumber daya yang dimiliki sehingga strategi untuk diterapkan dilapangan.

Ketiga, Tahap Evaluasi. Evaluasi strategi memiliki aktifitas yang fundamental, yaitu mereview faktor-faktor internal dan eksternal yang menjadi dasar untuk strategi saat ini. Mengukur performa dan mengambil langkah korektif. Fred R. David (2006: 5). ${ }^{24}$

\footnotetext{
${ }^{20}$ https://kalteng.kemenag.go.id/file/file/GONDO/5121567496646.pdf

${ }^{21} \mathrm{https} / / /$ peraturan.bpk.go.id/Home/Details/5451/pp-no-14-tahun-2014

22 https://peraturan.bpk.go.id/Home/Details/11384

${ }^{23}$ Hafidhuddin, Didin, Zakat Dalam Perekonomian Modern, Jakarta, Gema Insani Press,2002 hal.17

${ }^{24}$ Fred R David ,Management Stategik,Salemba, 2006 hal.5
} 
Al-Mutharahah: Jurnal Penelitian dan Kajian Sosial Keagamaan

Vol. 18 No. 1. Januari-Juni 2021

\section{SIMPULAN}

Kajian tentang pertumbuhan (growth) dan pembangunan (development) ekonomi dapat ditemukan dalam konsep ekonomi Islam. Solusi terbaik khususnya bangsa Indonesia ini adalah kembali ke Al Quran dan Sunnah karena Allah Azza Wa Jalla sudah memiliki formulasinya dalam mengelola dan membangun Dunia dengan segala sumber dayanya dengan konsep Syariah. Penulis Sebagai Komisioner Baznas Provinsi Riau memberikan masukan bahwa salah satu piranti Pembangunan Ekonomi yang Syar'i adalah lewat mekanisme Zakat Infaq dan Shadaqah (ZIS) dan Wakaf karena dengan yang pada pada akhirnya membawa keberkahan dan keadilan dalam hidup berbangsa dan bernegara. 


\section{DAFTAR PUSTAKA}

Al-Qur'anul Karim

Ahmad Ma'aruf dan Latri Wihastuti, Pertumbuhan Ekonomi Indonesia: Determinan dan Prospeknya, Jurnal Ekonomi dan Studi Pembangunan, Volume 9, Nomor 1, April 2008

Team Baznas Provinsi Riau, Buku saku Zakat , kalangan sendiri Pekanbaru Riau 2017

Chapra, M. Umer. Islam and Economic Development. Jakarta: Gema Insani, 2000.

Chapra, M. Umer. Islam and The Economic Challenge. Yogyakarta: Dana Bhakti Wakaf, 1998.

Hafidhuddin, Didin, Zakat Dalam Perekonomian Modern, Jakarta, Gema Insani Press, 2002 hal.17

Ahmad, Khursyid. 85.Al-Tanmiyah al-iqtisodiyah fi ithorin islamiyin, terjemah Rafiq Almisri, Majalah Abhas al-iqtisod al-islami, nomor 2, bagian 2.

Al-Fasi, Al-Syaikh Allal. Al-Islam wa mutatollabat al-tanmiyah fi mujtama' al-yaum.

Darran: Multaqa al-fikr al-Islami, 1971.

Yusuf, Ibrahim. Istiratijiyatu wa Tiknik al-Tanmiah al-Iqtisodiyah fi al-Islam. Kairo: AlIttihad al-Dauli li al-Bunuk al-Islamiyah, 1981.

Al-Mannan, Muhammad Abd. tt. Al-Iqtisâd al-Islâmi baina al-nazariyat wa al-tathbiq. AlMaktab al-ârabi al-hadis.

Chapra, M.Umer. Islam and Economic Development. USA: The Internasional Institute of Islamic Though (IIIT), 1992.

Yunus, Muhammad. The Poor as the Engine of Development dalam Economic Impact 2. (1988).

Al-Banna, Hasan. Majmu'at at-Rasai. Alexandaria: Darud Dakwah, 1989.

Mannan, M. Abdul. Islamic Economiys, Theory and Practice terj. M.Nastangin, Teori dan Praktek Ekonomi Islam Yogyakarta: Dana Bakti Waqaf, 1997.

Al-Tariqi, Abdullah Abdul Husein. Ekonomi Islam: Prinsip, Dasar dan Tujuan. Yogyakarta: Magistra Insania Press, 2004.

Beik,I.S. Ekonomic Role of zakat in Reducing Poverty Ang Income Inequality : A Case Study in the Province of DKI Jakarta, Indonesia, Deutschland; LAP Lambert Akademic, Publishing. 2013.

Qurroh Ayuniyyah dkk, The Comparison between Comsumption and Production-based Zakat Distribution Programs for Poverty Alleviation and Income Inequality Reduction, International Journal of Zakat Vol 2 (2) 2017

Https://peraturan.bpk.go.id/Home/Details/5451/pp-no-14-tahun-2014

Https://peraturan.bpk.go.id/Home/Details/11384

https://kalteng.kemenag.go.id/file/file/GONDO/5121567496646.pdf 